\section{A Two-step Procedure for Adventitious Shoot Regeneration from in vitro-derived Lingonberry Leaves: Shoot Induction with TDZ and Shoot Elongation Using Zeatin}

\author{
Samir C. Debnath ${ }^{1}$ \\ Atlantic Cool Climate Crop Research Centre, Agriculture and Agri-Food \\ Canada, St. John's, NL AlE 5Y7, Canada
}

Additional index words. plant regeneration, tissue culture, Vaccinium vitis-idaea, cytokinin, ex vitro rooting

\begin{abstract}
The effects of TDZ (0, 0.1, 1, 5 and $10 \mu \mathrm{M})$ and explant orientation on adventitious shoot regeneration of 'Erntedank'lingonberry were studied. Moderate concentration ( 1 to $5 \mu \mathrm{M}$ ) of TDZ supported bud and shoot regeneration, but strongly inhibited shoot elongation. TDZ initiated cultures were transferred to medium containing 1-2 $\mu \mathrm{M}$ zeatin and produced usable shoots after one additional subculture. Adventitious bud and shoot regeneration was greatly influenced by explant orientation. Elongated shoots were rooted on a 2 peat : 1 perlite (v/v) medium, and the plantlets were acclimatized and eventually established in the greenhouse with $80 \%$ to $90 \%$ survival rate.
\end{abstract}

The lingonberry (Vaccinium vitis-idaea L.), also called partridgeberry in the Canadian province Newfoundland and Labrador, is a circumboreal woody, rhizomatous, dwarf evergreen shrub (Luby et al., 1991; Vander Kloet, 1988) as well as a commercially important fruit crop (Gustavsson and Stanys, 2000; Jaakola et al., 2001), medicinal plant, and landscape ornamental ground cover (Gustavsson, 2001). Lingonberry fruit possesses a high anthocyanin content (Stark et al., 1978) which has important therapeutic values, including antitumor (Kamei et al., 1995; Koide et al., 1996), antiulcer (Cristoni and Magistretti, 1987), antioxidant, and anti-inflammatory activities (Wang et al., 1999). The berries and leaves are used medicinally to lower cholesterol levels and treat stomach disorders and rheumatic diseases as well as a bladder and kidney disinfectant (Novelli, 2003).

Due to an increasing demand for berries of high quality, a program to develop improved lingonberry cultivars using biotechnology and classical breeding was initiated in 1999. In vitro techniques are important tools for modern plant improvement programs (Taji et al., 2002). The ability to regenerate plants is crucial to the successful application of in vitro methods (Cao and Hammerschlag, 2000; Qu et al., 2000). A shoot regeneration system can be used to

Received for publication 21 Apr. 2004. Accepted for publication 12 July 2004. Atlantic Cool Climate Crop Research Centre contribution no. 170. The author gratefully acknowledges the cooperation of Boyd Penney who provided the plant material and reviewed the manuscript internally. Thanks are also due to Gary Bishop for internal manuscript review; and to Sarah Devine, Glen Chubbs, and Shawn Foley for their excellent technical help. I would like to acknowledge funding from the Canada Newfoundland Agricultural Safety Nets Initiative Program.

${ }^{1}$ Research scientist; e-mail debnaths@agr.gc.ca. identify and/or induce somaclonal variants and to develop transgenic plants following genetic transformation of plant cells.

Thidiazuron (TDZ), with its cytokinin- and auxin-like effects (Mok et al., 1982; Visser et al., 1992) induced in vitro shoot regeneration in kiwi (Suezawa et al., 1988), apple (Fasolo et al., 1989), grape (Matsuta and Hirabayshi, 1989), pear (Leblay et al., 1991), ohelo and bilberry (Shibli and Smith, 1996), and several woody plants (Huetteman and Preece, 1993). One disadvantage of TDZ is its often inhibitory effects on shoot elongation as demonstrated for several woody species (Huetteman and Preece, 1993) and cranberry (Marcotrigiano et al., 1996). Shoot inhibition occurs because the level of endogenous cytokinins is increased which inhibits the action of cytokinin oxidase (Hare et al., 1994). The objectives of the current study were to determine the response of lingonberry to TDZ for shoot regeneration from excised leaves, and for elongation of these regenerated shoots. The effectiveness of TDZ on in vitro elongation of adventitious shoots regenerated from leaf explants has not been demonstrated with Vaccinium species.

\section{Materials and Methods}

Plant material and preparation of stock cultures. Shoot tips of 'Erntedank' lingonberry were established following the method of Debnath and McRae (2001). Briefly, 4 to $6 \mathrm{~cm}$ shoot tips were surface disinfected in $\mathrm{NaOCl}$ plus $0.1 \%$ Tween 20 (polyoxyethylene sorbitan monolaurate)] for $20 \mathrm{~min}$ followed by a quick rinse in $70 \%$ ethanol; and then three rinses in sterile distilled water. Shoot tips were inoculated into $175-\mathrm{mL}$ glass baby-food jars containing $35 \mathrm{~mL}$ BM medium [three-quarter macrosalts and microsalts of Debnath and a $20 \%$ commercial bleach solution $[1.05 \%$
McRae's (2001) shoot proliferation medium D] supplemented with (per liter) $25 \mathrm{~g}$ sucrose, 3.5 g SigmaA 1296 agar, and $1.25 \mathrm{~g}$ Gelrite(Sigma Chemical Co., St. Louis). The medium $\mathrm{pH}$ was adjusted to 5.0 before autoclaving at $121{ }^{\circ} \mathrm{C}$ for $20 \mathrm{~min}$. Zeatin $(5 \mu \mathrm{M})$ was filter-sterilized and added to autoclaved and cooled (40 to 50 $\left.{ }^{\circ} \mathrm{C}\right) \mathrm{BM}$ medium. Cultures were maintained at $20 \pm 2{ }^{\circ} \mathrm{C}$ under a 16 -h photoperiod [photosynthetic photon flux (PPF) density of 30 $\mu \mathrm{mol} \cdot \mathrm{m}^{-2} \cdot \mathrm{s}^{-1}$ at the culture level] provided by cool white fluorescent lamps and subcultured every 8 weeks.

Experiment 1. Effects of TDZ concentration and explant orientation on adventitious shoot regeneration from leaf explants. Leaf explants were obtained from proliferating shoot cultures. All preculture operations of the leaves were performed on sterile filter-paper that was saturated with BM to prevent desiccation. Four almost-fully or fully expanded leaves nearest the apical meristem were excised with a scalpel at the petiole base and five transverse cuts were made through the midrib that did not severe the leaf completely. Prepared leaves (8) were transferred to $100 \times 25$-mm sterilized, disposable petri-plates containing $25 \mathrm{~mL}$ of BM containing $0,0.1,1,5$, or $10 \mu \mathrm{M}$ TDZ. The eight explants within each dish were oriented so that half were adaxial side down and the remaining four with their abaxial side in contact with the medium. Plates were sealed along the rim with two layers of Parafilm. A split-plot design with subsampling was used with TDZ concentrations assigned to their main plots and explant orientation as sub plots. Plates were arranged in the incubator randomly across treatments. There were four plates for each treatment and the experiment was conducted three times with a total of 60 plates. Cultures were incubated in the dark at 20 $\pm 2{ }^{\circ} \mathrm{C}$ for 2 weeks, before transfer to the same photoperiod, light intensity, and temperature used for multiplication.

Experiment 2. Effects of TDZ and zeatin on shoot elongation. Buds and shoot clumps from leaf explants of 'Erntedank' cultured on BM (adaxial side in contact with the medium) with $5 \mu \mathrm{M}$ TDZ were collected 8 weeks following culture initiation and randomly transferred to $175-\mathrm{mL}$ baby-food glass vessels (Sigma Chemical Co., St. Louis) containing $35 \mathrm{~mL}$ of BM with TDZ $(0.1$ or $1 \mu \mathrm{M})$, zeatin $(1$ or $2 \mu \mathrm{M})$ or BM void of plant growth regulators (control). Vessels were capped with polypropylene clear lids. There were four jars for each treatment and each jar contained five explants. The experiment was conducted three times.

Rooting and acclimatization. Elongated shoots ( 3 to $4 \mathrm{~cm}$ long) from BM with zeatin ( 1 or $2 \mu \mathrm{M})$ were excised just above the explant, dipped in 39.4 mM indole-3-butyric acid (IBA) powder (Stim-Root\#3, Plant Products Co.Ltd., Brampton, Ontario L6T 1G1, Canada) and planted in 45-cell plug trays (cell diameter: $5.9 \mathrm{~cm}$, cell depth: $15.1 \mathrm{~cm}$; Beaver Plastics, Edmonton, Alberta T5V 1H5, Canada) containing 2 peat : 1 perlite $(\mathrm{v} / \mathrm{v})$. Trays were placed in a humidity chamber with a vaporizer at 22 $\pm 2{ }^{\circ} \mathrm{C}, 95 \% \mathrm{RH}$ at $16 \mathrm{~h}$ photoperiod at 55 $\mu \mathrm{mol} \cdot \mathrm{m}^{-2} \cdot \mathrm{s}^{-1} \mathrm{PPF}$ for rooting. Plantlets were 

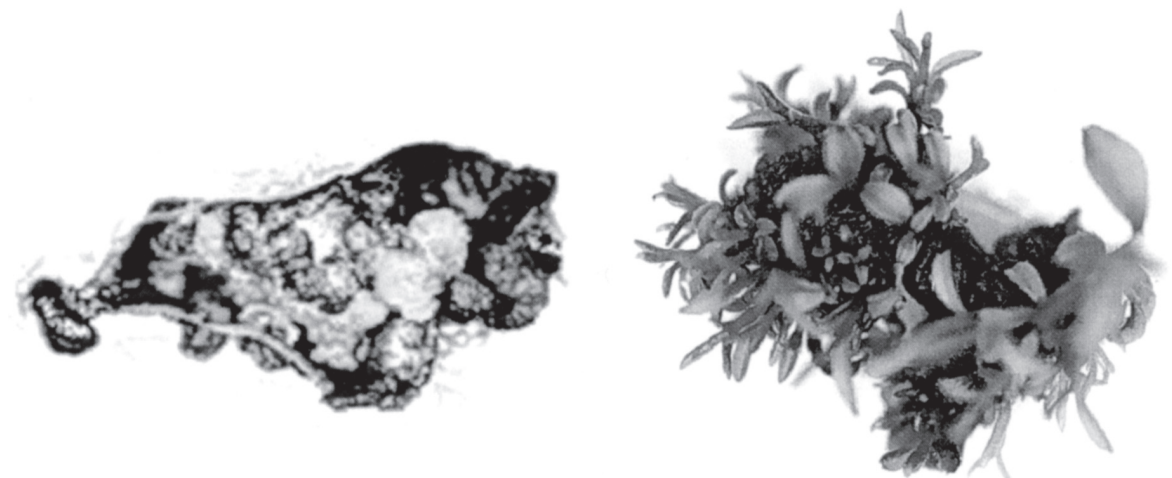

Fig. 1. Morphogenesis from lingonberry leaf explants of 'Erntedank' on BM supplemented with $5 \mu \mathrm{M}$ TDZ. (left) Morphogenesis occurred on leaf lamina and leaf edges 4 weeks after plating. (right) Shoot cluster developed from leaf explants 8 weeks after plating. transferred to $10.5(\mathrm{~L}) \times 10.5(\mathrm{~W}) \times 12.5(\mathrm{D})$ $\mathrm{cm}^{3}$ plastic pots containing the same medium as used for rooting, and acclimatized by gradually lowering the humidity over 2 to 3 weeks. Hardened-off plants were maintained in the greenhouse at $20 \pm 2{ }^{\circ} \mathrm{C}, 85 \% \mathrm{RH}$, and $16 \mathrm{~h}$ photoperiod at a maximum PPF of 90 $\mu \mathrm{mol} \cdot \mathrm{m}^{-2} \cdot \mathrm{s}^{-1}$. The number of surviving plants was recorded when they were removed from the humidity chamber (6 weeks).

Data collection and statistical analysis. In Expt. 1, after 8 weeks of incubation, the frequency of explants with callus and adventitious buds (longer than $1 \mathrm{~mm}$ ) or shoots (longer than $2 \mathrm{~mm}$ ), callus size, the number of buds and shoots per regenerating explant, and shoot vigor were recorded separately for each treatment. Vigor was assessed visually on a scale of 1 (strongly vitrified, necrotic and/or malformed shoots) to 8 (fully normal and healthy shoots). Callus was rated on a scale of no callus formation (0), and least (1) to greatest (8) growth.

For Expt. 2, the following growth characteristics of surviving explants were measured for each treatment at 8 weeks: number of shoots (>1 cm long) per responding explant, shoot length $(\mathrm{cm})$, number of leaves per shoot, shoot vigor, and callus size per explant. Vigor was determined by visual assessment, on a scale of 1 (strongly vitrified, necrotic and/or malformed shoots) to 8 (fully normal and healthy shoots with excellent vigor); $2=$ less vitrified, necrotic and/or malformed shoots; $3=$ no vitrification but with very poor vigor; $4=$ possessing poor shoot vigor; $5=$ with average shoot vigor; 6 $=$ having good shoot vigor; and $7=$ with very good shoot vigor. Callus size was rated as 0 (no callus formation), and 1 ( $<2 \mathrm{~mm}$ in diameter) to 8 (>14 $\mathrm{mm}$ in diameter).

Data for all characters except shoot vigor and callus size were subjected to analysis of variance with the SAS statistical software package (Release 8.2, SAS Institute, Inc., Cary, N.C.). The regeneration percentage was transformed to angles, and bud and shoot number per explant were transformed to the square root scale, before the ANOVA to stabilize the variance. In Expt. 1, data for the control treatment (0 PGR) were excluded from analysis because no explants responded. Statistical F tests were evaluated at $P \leq 0.05$. Differences among treat- ments were further analyzed using Duncan's multiple range test. Shoot vigor and callus size were analyzed separately by categorical analysis (CATMOD procedure in SAS) and differences between treatment combinations were contrasted using the contrast statement in the CATMOD procedure.

\section{Results and Discussion}

Effects of TDZ concentration and explant orientation on adventitious shoot regeneration form leaf explants. Explants grown on medium with different concentrations of TDZ, initially responded by callus formation not only on the cut edges and midribs, but also on the leaf lamina and leaf edges (Fig. 1). These changes were not observed in controls. Calli were initially green with reddish areas that are related to the sites of bud differentiation. Using a dissecting microscope, bud initials were observed on leaf explants 4 weeks after culture initiation. Multiple shoot-buds often occurred as tight bud clusters with some leaf expansion which varied by TDZ concentration. Adventitious buds appeared to regenerate directly or through a scar on the callus from both the abaxial and adaxial sides of the leaf, and some developed into shoots after 5 to 6 weeks of culture. Explants in treatments with a higher regeneration rate tended to have more buds and shoots per regenerating explant after 7 to 8 weeks of culture (Fig. 1).
An interaction $(P \leq 0.05)$ between leaf orientation and TDZ concentration was observed for shoot number (Table 1). These factors affected not only callus and bud regeneration percentages, number of buds and shoots developed per regenerating leaf explant (Table 1) but also shoot vigor (chi-square $=12.92, P$ $=0.0048)$ and callus size (chi-square $=12.80$, $P=0.0051)$. The induction of callus and buds was dependent on the addition of TDZ to the medium. Responding leaf explants produced more callus and shoots with increasing levels of TDZ up to $5 \mu \mathrm{M}$ (Tables 1 and 2). Across leaf orientations, the percentage of explants producing callus and adventitious buds was highest at $5 \mu \mathrm{M}$ TDZ. However, more adventitious buds were formed on explants incubated in BM with $10 \mu \mathrm{M}$ TDZ (Table 1). Shoot vigor was best at $1 \mu \mathrm{M}$ of TDZ and declined at higher TDZ concentrations (Table 2). media is an important factor in increasing the morphogenic response of many woody species (Welander, 1988). In the present study, shoot regeneration in lingonberry occurred on both sides of the leaves as was reported previously (Debnath and McRae, 2002) and for cranberry (Marcotrigiano et al., 1996). However, Qu et al. (2000) reported that shoot regeneration in cranberry was almost exclusively from the adaxial side. In blueberry, both adaxial down (Billings et al., 1988; Rowland and Ogden, 1992) and up (Callow et al., 1989) have been used in leaf regeneration. In this study, although shoot regeneration occurred with both explant orientation treatments, the greatest explant response occurred when the adaxial side was in contact with the medium. Adventitious shoot production, with respect to regeneration percentage and number of buds and shoots per explant, was significantly reduced when explants were cultured with their abaxial surface in contact with the medium (Table 1). Possibly, the adaxial surface is more responsive to nutrients because it is the last tissue of the leaf to cease growing and dividing (Welander, 1988).

Effects of TDZ and zeatin on shoot elongation. Shoot elongation and proliferation was best when adventitious buds and shoots formed on BM supplemented with $5 \mu \mathrm{M}$ TDZ were transferred to BM containing zeatin compared
Orientation of leaf explants on regeneration

Table 1. Effects of TDZ concentration and leaf explant orientation (adaxial side down = Ad, abaxial side down $=\mathrm{Ab}$ ) on the frequency of callus formation and bud regeneration, and for bud and shoot number per regenerating explants from leaves of lingonberry cultivar, 'Erntedank'z.

\begin{tabular}{lcccc}
\hline & $\begin{array}{c}\text { Callus } \\
\text { regeneration } \\
\% \text { (angles) }\end{array}$ & $\begin{array}{c}\text { Bud } \\
\text { regeneration } \\
\% \text { (angles) }\end{array}$ & $\begin{array}{c}\text { Buds } \\
(\sqrt{ } \text { no./explant })\end{array}$ & $\begin{array}{c}\text { Shoots } \\
(\sqrt{ } \text { no./explant })\end{array}$ \\
\hline Treatment & $39 \mathrm{~d}^{\mathrm{y}}$ & $33 \mathrm{~d}$ & $2.1 \mathrm{~d}$ & $1.7 \mathrm{~d}$ \\
0.1 & $55 \mathrm{c}$ & $50 \mathrm{~b}$ & $2.5 \mathrm{c}$ & $2.5 \mathrm{~b}$ \\
1.0 & $78 \mathrm{a}$ & $60 \mathrm{a}$ & $2.9 \mathrm{~b}$ & $2.7 \mathrm{a}$ \\
5.0 & $60 \mathrm{~b}$ & $40 \mathrm{c}$ & $3.5 \mathrm{a}$ & $2.2 \mathrm{c}$ \\
10.0 & & & & $2.3 \mathrm{a}$ \\
Explant orientation & $60 \mathrm{a}$ & $48 \mathrm{a}$ & $2.6 \mathrm{~b}$ & $2.2 \mathrm{~b}$ \\
Ad & $56 \mathrm{~b}$ & $43 \mathrm{~b}$ & $\mathrm{~T}, \mathrm{E}$ & $\mathrm{T}, \mathrm{E}, \mathrm{T} \times \mathrm{E}$ \\
Ab & $\mathrm{T}, \mathrm{E}$ & $\mathrm{T}, \mathrm{E}$ & & \\
Significant effects & & & & \\
\hline
\end{tabular}

${ }^{\mathrm{z}}$ Data were collected after 8 weeks in culture.

${ }^{y}$ Mean separation within columns and factors by Duncan's multiple range test, $P \leq 0.05$, whereby means associated with different letters signify significant differences.

${ }^{x}$ Significant effects $(P \leq 0.05)$ : $\mathrm{T}=\mathrm{TDZ}$ concentration, $\mathrm{E}=$ explant orientation. 
Table 2. Effects of TDZ concentration and leaf explant orientation (adaxial side down = Ad, abaxial side down $=\mathrm{Ab}$ ) on shoot vigor and callus size per regenerating explants from leaves of lingonberry cultivar, 'Erntedank'z.

\begin{tabular}{|c|c|c|c|c|}
\hline \multirow{2}{*}{$\begin{array}{l}\text { TDZ } \\
\text { concn } \\
(\mu \mathrm{M})\end{array}$} & \multicolumn{2}{|c|}{$\begin{array}{l}\text { Shoot vigor } \\
(\text { scale } 1-8)^{\mathrm{y}}\end{array}$} & \multicolumn{2}{|c|}{$\begin{array}{l}\text { Callus size } \\
(\text { scale } 0-8)^{x}\end{array}$} \\
\hline & Ad & $\overline{\mathrm{Ab}}$ & Ad & $\mathrm{Ab}$ \\
\hline 0.1 & 5.3 & 4.8 & 3.3 & 2.9 \\
\hline 1.0 & 6.0 & 5.8 & 4.0 & 3.8 \\
\hline 5.0 & 4.7 & 4.2 & 5.3 & 5.0 \\
\hline 10.0 & 3.9 & 3.5 & 4.7 & 4.4 \\
\hline Significant effects ${ }^{w}$ & \multicolumn{2}{|c|}{$\mathrm{T}$} & \multicolumn{2}{|c|}{$\mathrm{T}$} \\
\hline Significant contrasts $[\mathrm{T}(\mu \mathrm{M})]$ & \multicolumn{2}{|c|}{$\begin{array}{c}0.1 \text { vs. } 10.0(P=0.0269) \\
1.0 \text { vs. } 5.0(P=0.0293) \\
1.0 \text { vs. } 10.0(P=0.0005)\end{array}$} & \multicolumn{2}{|c|}{$\begin{array}{c}0.1 \text { vs. } 5.0(P=0.0006), \\
0.1 \text { vs. } 10.0(P=0.0128), \\
1.0 \text { vs. } 5.0(P=0.0442)\end{array}$} \\
\hline
\end{tabular}

${ }^{2}$ Data were collected after 8 weeks in culture.

Vigor was assessed visually on a scale of 1 (strongly vitrified, necrotic and/or malformed shoots) to 8 (fully normal and healthy shoots).

${ }^{x}$ Callus was rated on a scale of no callus formation (0), and least (1) to greatest (8) growth.

wignificant effects $(P \leq 0.05)$ : T $=$ TDZ concentration.

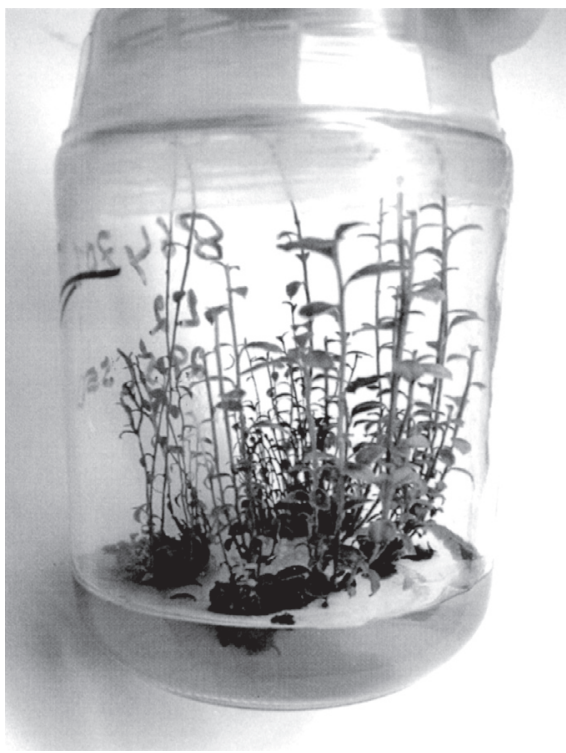

Fig. 2. Elongated adventitious shoots on $1 \mu \mathrm{M}$ zeatin-containing medium 8 weeks after transfer of 8 -week-old thidiazuron $(5 \mu \mathrm{M})$-induced 'Erntedank' shoots from leaf explant.

to TDZ and no PGR (Table 3). While shoot height was greatest at $1 \mu \mathrm{M}$ zeatin, the number of shots per responding explant was better at $2 \mu \mathrm{M}$ zeatin. Shoot vigor was similar at both zeatin concentrations. Responding explants transferred to BM without PGRs became necrotic and died within 8 weeks.

Table 3. Effects of TDZ (T) and zeatin (Z) concentration on shoot elongation 8 weeks after transfer of 8 -week-old thidiazuron ( $5 \mu \mathrm{M})$-induced 'Erntedank' shoots from leaf explant.

\begin{tabular}{lccccc}
\hline $\begin{array}{l}\text { Cytokinin } \\
\text { concn } \\
(\mu \mathrm{M})\end{array}$ & $\begin{array}{c}\text { Shoots } \\
(\text { nno./explant })\end{array}$ & $\begin{array}{c}\text { Shoot } \\
\mathrm{ht} \\
(\mathrm{cm})\end{array}$ & $\begin{array}{c}\text { Leaves } \\
(\text { no./shoot })\end{array}$ & $\begin{array}{c}\text { Shoot } \\
\text { vigor } \\
(\text { scale 1-8) })^{\mathrm{z}}\end{array}$ & $\begin{array}{c}\text { Callus } \\
(\text { scale 0-8) }\end{array}$ \\
\hline 0.0 & $2.7 \mathrm{e}^{\mathrm{x}}$ & $4.3 \mathrm{c}$ & $5.6 \mathrm{c}$ & $3.5 \mathrm{c}$ & $3.6 \mathrm{c}$ \\
$\mathrm{T}=0.1$ & $3.9 \mathrm{~d}$ & $2.6 \mathrm{~d}$ & $3.4 \mathrm{~d}$ & $3.9 \mathrm{bc}$ & $6.9 \mathrm{ab}$ \\
$\mathrm{T}=1.0$ & $4.5 \mathrm{~b}$ & $2.0 \mathrm{e}$ & $3.2 \mathrm{~d}$ & $3.4 \mathrm{c}$ & $7.7 \mathrm{a}$ \\
$\mathrm{Z}=1.0$ & $4.2 \mathrm{c}$ & $6.0 \mathrm{a}$ & $8.0 \mathrm{a}$ & $6.3 \mathrm{a}$ & $5.4 \mathrm{~b}$ \\
$\mathrm{Z}=2.0$ & $4.9 \mathrm{a}$ & $5.3 \mathrm{~b}$ & $6.8 \mathrm{~b}$ & $5.2 \mathrm{ab}$ & $6.2 \mathrm{ab}$ \\
\hline
\end{tabular}

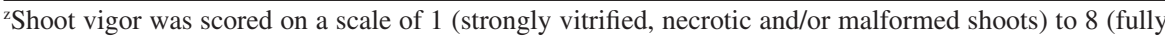
normal and healthy shoots with excellent vigor); $2=$ less vitrified, necrotic and/or malformed shoots; $3=$ no vitrification but with very poor vigor; $4=$ possessing poor shoot vigor; $5=$ with average shoot vigor; 6 $=$ having good shoot vigor; and $7=$ with very good shoot vigor.

${ }^{y}$ Callus size was rated as 0 (no callus formation) and 1 ( $<2 \mathrm{~mm}$ in diameter) to 8 (>14 mm in diameter). ${ }^{x}$ Mean separation within columns for shoot number, shoot height, and leaf number per shoot by Duncan's multiple range test, and for shoot vigor and callus size by categorical analysis (CATMOD procedure in SAS), $P \leq 0.05$, whereby means associated with different letters signify significant differences. usable shoots after one additional subculture. Zeatin was also found to be effective for shoot initiation in Vaccinium species (Reed and Abdelnour-Esquivel, 1991), and shoot proliferation of lingonberry (Debnath and McRae, 2001) and highbush blueberry (Chandler and Draper, 1986; Eccher and Noe, 1989). After acclimatization, plantlets grew actively in the greenhouse with no apparent leaf and shoot abnormalities.

\section{Literature Cited}

Billings, S.G., C.K. Chin, and G. Jelenkovic. 1988. Regeneration of blueberry plantlets from leaf segments. HortScience 23:763-766.

Callow, P., K. Haghighi, M. Giroux, and J. Hancock. 1989. In vitro shoot regeneration on leaf tissue from micropropagated highbush blueberry. HortScience 24:373-375.

Cao, X. and F.A. Hammerschlag. 2000. Improved shoot organogenesis from leaf explants of highbush blueberry. HortScience 35:945-947.

Capelle, S.C., D.W.S. Mok, S.C. Kirchner, and M.C. Mok. 1983. Effects of thidiazuron on cytokinin autonomy and the metabolism of $N^{6}-\mathrm{C}^{2}$ isopentenyl[ $\left[18^{-14} \mathrm{C}\right]$ adenosine in callus tissues of Phaseolus lunatus L. Plant Physiol. 73:796-802.

Chandler, C.K. and A.D. Draper. 1986. Effect of zeatin and $2 \mathrm{iP}$ on shoot proliferation of three highbush blueberry clones in vitro. HortScience 21:1065-1066.

Cristoni,A. and M.J. Magistretti. 1987. Antiulcer and healing activities of Vaccinium mytrillus anthiocyanosides. Farmaco [Pratica] 42:29-43.

Debnath, S.C. and K.B. McRae. 2001. In vitro culture of lingonberry (Vaccinium vitis-idaea L.): The influence of cytokinins and media types on propagation. Small Fruits Rev. 1:3-19.

Debnath, S.C. and K.B. McRae. 2002. An efficient adventitious shoot regeneration system on excised leaves of micropropagated lingonberry (Vaccinium vitis-idaea L.). J. Hort. Sci. Biotechnol. 77:744-752.

Eccher, T. and N. Noe. 1989. Comparison between $2 \mathrm{iP}$ and zeatin in the micropropagation of highbush blueberry (Vaccinium corymbosum). Acta. Hort. 441:185-190.

Fasolo, F., R.H. Zimmerman, and I. Fordham. 1989. Adventitious shoot formation on excised leaves of in vitro grown shoots of apple. Plant Cell Tiss. Org. Cult. 16:75-87.

Gill, R. and P.K Saxena. 1992. Direct somatic embryogenesis and regeneration of plants from seedling explants of peanut (Arachis hypogeae): promotive role of thidiazuron. Can. J. Bot. 70:1186-1192.

Gustavsson, B.A. 2001. Genetic variation in horticulturally important traits of fifteen wild lingonberry Vaccinium vitis-idaea L. populations. Euphytica 120:173-182

Gustavsson, B.A. and V. Stanys. 2000. Field performance of 'Sanna' lingonberry derived by micropropagation vs. stem cuttings. HortScience 35:742-744.

Hare, P.D., J. Staden, and J. Van Staden. 1994. Inhibitory effect of TDZ on the activity of cytokinin oxidase isolated from soybean callus. Plant Cell Physiol. 35:1121-1125.

Huetteman, C.A. and J.E. Preece. 1993. Thidiazuron: a potent cytokinin for woody plant tissue culture. Plant Cell Tiss. Org. Cult. 33:105-119.

Jaakola, L., A. Tolvanen, K. Laine, and A. Hohtola. 2001. Effect of $\mathrm{N}^{6}$-isopentenyladenine concentration on growth initiation in vitro and rooting of bilberry and lingonberry microshoots. Plant Cell Tiss. Org. Cult. 66:73-77. 
Kamei, H., T. Kojima, M. Hasegawa, T. Koide, T. Umeda, T. Yukawa, and K. Terabe. 1995. Suppression of tumor cell growth by anthocyanins in vitro. Cancer Invest. 13:590-594.

Koide, T., H. Kamei, Y. Hashimoto, T. Kojima, and M. Hasegawa. 1996. Antitumor effect of hydrolyzed anthocyanin from grape rinds and red rice. Cancer Biother. Radiopharm. 11:273-277.

Leblay, C., R. Chevreau, and L.M. Raboin. 1991. Adventitious shoot regeneration from in vitro leaves of several pear cultivars (Pyrus communis L.). Plant Cell Tiss. Org. Cult. 25:99-105.

Luby J.J., J.R. Ballington, A.D. Draper, K. Pliszka, and M.E.Austin. 1991. Blueberries and cranberries (Vaccinium). Acta Hort. 290:391-456.

Marcotrigiano, M., S.P. McGlew, G. Hackett, and B. Chawla. 1996. Shoot regeneration from tissue-cultured leaves of the American cranberry (Vaccinium macrocarpon). Plant Cell Tiss. Org. Cult. 44:195-199.

Matsuta N. and T. Hirabayshi. 1989. Embryogenic cell lines from somatic embryos of grape (Vitis vinifera L.). Plant Cell Rpt. 7:684-687.

Mok, M.C., D.W.S. Mok, D.J.Armstrong, K. Shudo, Y. Isogai, and T. Okamoto. 1982. Cytokinin activity of $N$-phenyl- $N$-1,2,3-thiadizol-5-ylurea (thidiazuron). Phytochemistry 21:1509-1511.

Novelli, S. 2003. Developments in berry produc- tion and use. Agr. Agri-Food Can. Bi-weekly Bul. 16(21)

Qu, L., J. Polashock, and N. Vorsa. 2000. A high efficient in vitro cranberry regeneration system using leaf explants. HortScience 35:948-952.

Reed, B.M. and A. Abdelnour-Esquivel. 1991. The use of zeatin to initiate in vitro cultures of Vaccinium species and cultivars. HortScience 26:1320-1322.

Rowland, L.J. and E.I. Ogden. 1992. Use of a cytokinin conjugate for efficient shoot regeneration from leaf sections of highbush blueberry. HortScience 27:1127-1129.

Russel, J.A. and B.H. McCown. 1986. Thidiazuron stimulated shoot differentiation from protoplast derived calli of Populus, p. 49. In: Abstracts of 6th Intl. Cong. on Plant Tissue and Cell Cultures, Univ. Minn., Minneapolis.

Shibli, R. and M.A.I. Smith. 1996. Direct shoot regeneration from Vaccinium pahalae (ohelo) and V. myrtillus (bilberry) leaf explants. HortScience 31:1225-1228.

Stark, R., I.V. Hall, and P.A. Hendrickson. 1978. The partridgeberry of Newfoundland. Canadex (Hort. Crops) 230

Suezawa, K., N. Matsuta, M. Omura, and S. Yamaki. 1988. Plantlet formation from cell suspensions of kiwi fruit (Actinidia chinensis Planch. var. chinensis). Sci. Hort. 37:123-128.

Taji, A., P.P. Kumar, and P. Lakshmanan. 2002 In vitro plant breeding. Food Products Press, New York.

Thomas, J.C. and F.R. Katterman. 1986. Cytokinin activity induced by thidiazuron. Plant Physiol. 81:681-683.

van Nieuwkerk, J.P., R.H. Zimmerman, and I Fordham. 1986. Thidiazuron stimulation of apple shoot proliferation in vitro. HortScience 21:516-518.

Vander Kloet, S.P. 1988. The genus Vaccinium in North America. Agr. Can. Publ. 1828.

Visser, C., J.A. Qureshi, R. Gill, and P.K. Saxena. 1992. Morphoregulatory role of thidiazuron: substitution of auxin and cytokinin requirement for the induction of somatic embryogenesis in geranium hypocotyl cultures. Plant Physiol. 99:1704-1707.

Wang, H., M.G. Nair, M. Strasburg, Y.C. Chang, A.M. Booren, J.I. Gray, and D.L. DeWitt. 1999. Antioxidant and antiinflammatory activities of anthocyanins and their aglycon, cyanidin, from tart cherries. J. Nat. Prod. 62:294-296.

Welander, M. 1988. Plant regeneration from leaf and stem segments of shoots raised in vitro from mature apple trees. J. Plant Physiol. 132:738-744. 